\title{
REFLECTIONS ON THE History OF THE INDIAN OCEAN: the sources and their relation to local practices and global connectivities
}

\author{
Transforming Cultures eJournal, \\ Vol. 4 No 2 November 2009 \\ http://epress.lib.uts.edu.au/journals/TfC
}

\section{Anne K. Bang ${ }^{1}$}

\begin{abstract}
This paper discusses the interpretation of sources for Indian Ocean history, from the point of view of translocal interpretations beyond the locality of the source. The article presents three cases, all deriving from the Muslim South-Western Indian Ocean. The argument is made that the ambiguity of the sources, and the interrelationship between the various locations related to the source, affect not only the historians interpretation but also the sense of the past held by people in these locations.

[Islam, translocality, South-Western Indian Ocean]
\end{abstract}

The peoples of the Indian Ocean rim have, throughout known history, lived in various types of societies on the shores of the sea. They have dwelled, resided, stayed, lived and died in their respective places- very few have lived their lives permanently on boats crossing from this port to that. Lives, in short, are local, in the sense that they are constituted and interpreted locally, within the boundaries of the local.

Nonetheless, in the past two decades, the field of Indian Ocean studies has manifested a specific discourse which goes beyond the local and focuses instead on inter-civilizational encounters and the ensuing cultural change. Words like "hybrid", "polyphonic", "cosmopolitan", "pluralist", "multi-cultural" can be found in most academic works on

\footnotetext{
${ }^{1}$ Anne Bang teaches at the department of History at the University of Bergen. She is also a research leader at the research institute Uni Global in Bergen where she is currently involved in research on Islamic history in the Indian Ocean.
} 
Indian Ocean culture and history and reflect the emphasis on movement and exchange as starting points. Authors of full-scale Indian Ocean histories have tended to focus on migration resulting from the regularity of the monsoon, emphasizing trade, religious linkages or family networks spanning the ocean. ${ }^{2}$ The reason for this focus is obvious: the societies of the Indian Ocean rim bear such clear imprints of each other - testimony to persistent and pervasive cultural contact over the millennia - that these simply cannot be overlooked. This historical and ongoing economic, religious and cultural connectivity has also been the topic of more recent regional studies that single out specific groups that have played important roles in the Indian Ocean world. For example, several authors have described the region of Hadramawt in southern Yemen as an exporter of human capital and of goods, beliefs, political systems, thoughts and ideas that flowed from Arabia to the diaspora - and back as travelers returned, sometimes generations later. ${ }^{3}$ Other studies have also emerged that view the Western Indian Ocean as a cultural continuum in which intellectual, material and economic currents flowed (and flow) between localities, unbounded by distance, colonial interventions or state formations. ${ }^{4}$

What these studies have in common is the concept of translocality, both as an overarching research perspective and as reference to empirical realities. However, what these studies also have in common is the problematic (and to varying degrees resolved) relationship between local narratives and the wider, global history into which they inevitably play. In localities, perceptions of the present world - and the past world - are created and re-

${ }^{2}$ K.N. Chaudhuri (1985) Trade and Civilization in the Indian Ocean: An economic history from the rise of Islam to 1750, New York: Cambridge University Press and M.N. Pearson (2003) The Indian Ocean, London: Routledge. See also, A. Sheriff (2009) Dhow Culture, London: Hurst.

${ }^{3}$ See, for example, Natalie Mobini-Kesheh (1999) The Hadrami Awakening. Community and Identity in the Netherlands East Indies, 1900-1942, Ithaca: Cornell University (SEAP); Ulrike Freitag (2003) Indian Ocean Migrants and State Formation in Hadhramaut. Reforming the homeland, Leiden: Brill; K. Arai (2004) Arabs who traversed the Indian Ocean: The history of the al-Attas family in Hadramawt and Southeast Asia c. 16001960, Ph.D. Thesis, University of Michigan; Engseng Ho (2006) The Graves of Tarim. Genealogy and Mobility across the Indian Ocean, Berkeley: University of California Press.

${ }^{4}$ See for example A.K. Bang (2003) Sufis and Scholars of the Sea. Family networks in East Africa, c. 18601925, London: Routledge-Curzon; R. Loimeier \& R. Seesemann (eds.) (2006) The Global Worlds of the Swahili. Interfaces of Islam, Identity and Space in $19^{\text {th }}$ and $20^{\text {th }}$ century East Africa, Munster: LIT Verlag; K. Kresse \& E. Simpson (eds.) (2007) Struggling with History. Islam and Cosmopolitanism in the Western Indian Ocean, London: Hurst; J. Prestholdt (2008) Domesticating the World. African Consumerism and the Genealogies of Globalization, Berkeley: University of California Press; R. Loimeier (2009) Between Social Skills and Marketable Skills. The politics of Islamic education in $20^{\text {th }}$ century Zanzibar, Leiden: Brill. 
created. In these localities are also produced what historians call "sources" - be they written, material or transmitted in the form of narratives.

The relationship between the source, the locality and the other locations it directly or indirectly refers to, is one that the historian of the Indian Ocean (or of the localities of the Indian Ocean) will need to ponder. Below, I will present three different sources, each used for writing Indian Ocean history, and I will focus on the varying relationship between the source and the context in which it was generated. There is a range of interpretations possible for this type of material. ${ }^{5}$ The issue to keep in mind is how the source material reflects both the locality in which it was produced as well as the connectivity which created its nature and its content.

\section{Source 1: Landing Permit for Sayyid Ahmad b. Abd Allah al-Hibshi in} Cape Town, February 1913: Muslim Communities in Contact

On the $22^{\text {nd }}$ February 1913, one Sayyid Ahmad b. Abd Allah al-Hibshi stepped ashore in Cape Town from the steamer S/S General. ${ }^{6}$ Ahmad al-Hibshi had embarked at Zanzibar, at that time a well-established centre of Islamic learning for the East African coast. Al-Hibshi was duly equipped with a passport issued by the British Consul General of the Zanzibar Protectorate - the passport being dated $27^{\text {th }}$ December 1912. Al-Hibshi travelled as a deck passenger, and he was 48 years of age when he arrived in Cape Town. His stated profession was that of "businessman", while also being referred to as a "priest". According to the immigration paper, he was an "Arab" and he duly signed his name in the Arabic script, being (upon direct question) unable to sign in Latin script. His name, though, identifies him as a descendant of the sharifian/sada strata of Hadramawt. According to his passport, alHibshi was born in the city of Shibam in Hadramawt, Yemen. Interestingly, his passport

\footnotetext{
${ }^{5}$ The three cases discussed here originate in field work conducted at various points in time between 2002 and 2008, as part of a post-doc project and later as part of the Indian Ocean research project at the University of Bergen entitled "Linking Global Cities, tracing local practices" (http://global.uib.no/home/index.php?module=article\&view=57). The Cape Town archival material was collected in 2007, while field work in Antsiranana (Diego Suarez) was conducted in 2008. As for the sources used for the "Meccan waqfs" in Zanzibar, these are spread between the Zanzibar National Archives and the manuscript collection owned by the late Ahmad Al Bu Saidi in Muscat, Oman, both of which were visited on repeated occasions during the period.

${ }^{6}$ South African National Archives, Cape Town: KAB-IRC-1/1/347/987A: Immigration papers, Sharif Ahmad b. Abd Allah al-Habashi.
} 
gives al-Hibshi's status to be that of "British Protected Subject", i.e. originally resident in one of the British colonies (in this case most likely Aden, but possibly also India). AlHibshi came to Cape Town for another reason, namely to visit two of his otherwise unidentified relatives, living in Rose Street, Cape Town. In other words, he came as part of a network.

Strictly speaking, this document is merely one of many that tell the story of persistent immigration into Cape Town in the early $20^{\text {th }}$ century and the rise of the new Union of South Africa following the Boer War. Many were European, others were Indian, Southeast Asian or African, and some were Arabs. In other words, the Cape Town immigration records represent the sources of the present-day narrative of the modern "rainbow nation".

However, this document should also be seen as a testimony to how global flows of the Indian Ocean in this period also reached the far corners of the sea - how Indian Ocean migration itself reached a high tide in the early $20^{\text {th }}$ century - much aided by the steamship lines and organized travel. The global flow represented by al-Hibshi had a name - or rather, a purpose. He came for $d a^{\prime} w a$ - to preach religion to people who were already Muslims, in other words as a reformist-oriented teacher. In his immigration papers, al-Hibshi expressed his intention to "visit co-religionists", which indicates the religious purpose of his visit. His departure papers notes that he has been preaching in mosques during his stay. ${ }^{7}$ In this, he was not alone. The ships travelling the Western Indian Ocean at this time had many passengers who were traveling for $d a^{\prime} w a$ - to spread "rays of light" to fellow Muslims, sometimes on the latter's expressed invitation, at other times of their own volition. The impact of these travellers on local Islamic practice has yet to be fully studied in its different contexts, but their presence raises a series of questions. When ritual practice spreads, is it merely relocated? I will argue that with relocation follows specific reinterpretation, depending on time and space. One example is the Ratib al-Haddad, a poetic recitation expressing a reformist type of Sufism propagated precisely by scholars such as our travelling Hibshi. Recited in Hadramawt, Lamu, Zanzibar, Diego Suarez or Cape Town, its connotations, implications and its features would all be different, depending on political,

\footnotetext{
${ }^{7}$ South African National Archives, Cape Town: KAB-IRC-1/1/347/987A: Immigration papers, Sharif Ahmad b. Abd Allah al-Habashi.
} 
economic, linguistic, and social environments. Thursday night recitations in Yemen in the mid-1960s did not have the same implications as the same event in Cape Town in the 1970s, where it took on hues of anti-apartheid resistance.

Globalization, whichever way interpreted, is bound to generate conflict, for the simple reason that "new" will meet "old" (or "reform" meet "tradition") at some stage, in particular settings, at particular times. This was clearly the case when Sufism, as an organized way of Islamic worship, was introduced into East Africa in the late $19^{\text {th }}$ century. As has been pointed out by several authors, most recently by Roman Loimeier, ${ }^{8}$ controversies over changing practices take place in a social context whereby established power-structures (economic, political and status-related) play into a debate that is phrased in religious terms. In Zanzibar, Lamu, and on the East African coast in general, the expansion of the new Sufi orders challenged existing social orders both in terms of legitimacy and religious interpretation. Thus, $d a^{\prime} w$ a, and in this case $d a^{\prime} w a$-based Sufism which actively recruited for what they themselves perceived as reform, functioned not only as a reform of religious tenets but also - potentially, at least - of social order. Translocality, in other words, is here not only a perspective, but also a process, still ongoing but with deep roots. Through this process, Islam was - and is - continuously "updated", in the sense that the normative is confronted with local variations. It is important, however, to note that this encounter does not automatically lead to the gradual takeover of the normative - or the "global". As has been discussed, for example by F. Becker, religious innovations are as much reflections of collective social and personal needs as wholesale rejections of the "old". ${ }^{9}$ Countermovements are also regular occurrences. In Zanzibar nowadays, there are movements actively countering the impact of Salafi/Wahhabi missionary activities, drawing explicitly on local traditions, local ritual practice and local teachers. ${ }^{10}$

\footnotetext{
${ }^{8}$ R. Loimeier (2006) “Zum sozialen Kontext eines religiösen Rituals”, Der Islam 83: 170-186.

${ }^{9}$ F. Becker (2008) Becoming Muslim in Mainland Tanzania, 1890-2000, Oxford: Oxford University Press.

${ }^{10}$ Personal observations, Zanzibar, 2006-2009.
} 
Source 2: Receipts for Waqf Transactions from Zanzibar to Mecca (The "Meccan Waqfs"): Evidence of a Booming City and of Pious Connections

By the mid- $19^{\text {th }}$ century, each major Sufi order would be represented in Mecca by their awiyyas - normally large houses that functioned as a combination of boarding house, cantine and spiritual centre. Through these centres, and through the pilgrimage, the Haramayn was also a centre for Indian Ocean Islam in the period. It would, however, be incorrect to view Mecca as a place filled with Arab scholars imparting their Arab knowledge to Swahilis, Malays and other non-Arabs. As travel became more widespread, it became a place where scholars of all tribes, languages and ethnicities converged and debated, using the scholarly lingua franca, Arabic. In sum, both Mecca and Medina were truly cosmopolitan, to an extent which led Snouck Hurgronje to note that: "Mecca is partly a town of foreigners" - a "many-tongued mass of humanity". ${ }^{11}$

In Mecca and Medina were also the "great scholars of the age", most notably the theologians and jurists of the different law-schools. These would teach in the Haram mosque and in the Nabawi (Prophet's) mosque in Medina according to fixed schedules. Among these, by far the most influential was Ahmad Zayni Dahlan (1817-1886), the Shafii mufti from 1871 and a teacher much-sought after by students from the Indian Ocean. ${ }^{12}$ Indeed, Dahlan's connection with the Indian Ocean world was close and multi-faceted, and his impact on East African Sufi practices and Islamic scholarship was to be long-standing. Firstly, he himself studied with a number of Hadrami Alawis, many of whom had family branches in East Africa as well as in the wider Indian Ocean. Then, he became a teacher for new generations of ulama from Indian Ocean lands - both of Hadrami origin and others, being anti-Wahhabi but stressing also the need for adherence to Sharia moral codes. ${ }^{13}$ This view was shared by Dahlan's "second-in-command", Muhammad Said Babsayl or (Ba Busayl) (d. 1912), a scholar of Hadrami origin. Like his mentor, Babsayl

\footnotetext{
${ }^{11}$ C. Snouck Hurgronje (2007) Mecca in the latter half of the $19^{\text {th }}$ century, Leiden: Brill, 205-206.

12 This section draws on the work of U. Freitag (1999) "Hadramaut: A religious Centre for the Indian Ocean in the late $19^{\text {th }}$ and Early $20^{\text {th }}$ centuries?" Studia Islamica 89: 165-83 and (2003) "Der Orientalist und der Mufti: Kulturkontakt im Mekka des 19. Jahrhunderts", Die Welt des Islams, 43 (1): 37-60.

${ }^{13}$ The exposition of Ahmad Zayni Dahlan's defence of Sufism can be gained from his work (1980) Al-Durr al-Saniyya fi 'l-radd al-Wahhabiyya, 4th ed., Cairo ND.
} 
wrote a treatise in defence of Sufi practices. ${ }^{14}$ He was also a well-known teacher - amongst others he is reported to have held special sessions for women on Friday mornings. A third important teacher was Abu Bakr b. Muhammad Shatta (d. 1893), known in Mecca as Sayyid Bakri. ${ }^{15}$ In their lifetimes, these three men were important teachers for two generations of Zanzibari/East African scholars. As we shall see, the connection was not only intellectual and it did not end with their deaths.

The first generation of Shaafi scholars emerging under Bu Saidi auspices in East Africa included such men as Muhyi al-Din al-Qahtani (ca. 1790-1869), Abd al-Aziz b. Abd alGhani al-Amawi (1838-1896), Ali b. Abd Allah b. Nafi al-Mazrui (1825-1894) and Ali b. Khamis al-Barwani (1852-1885). ${ }^{16}$ This generation travelled widely, and studied with numerous scholars, although only al-Mazrui is known for certain to have spent time in Mecca with Ahmad Zayni Dahlan.

The Haramayn becomes an even more noticable influence in the second generation, which came into positions of importance in the early colonial period. Here we find, most notably, the later Chief Sunni Qadi of Zanzibar, Ahmad b. Abu Bakr b. Sumayt (1861-1925). Although he did not study directly with Dahlan (who had died by the time Ibn Sumayt arrived), he spent time with Babsayl and Shatta. Ahmad b. Sumayt's disciple and close companion in Zanzibar, Abd Allah Ba Kathir (1860-1925), made the same journey in 1897, seeking out the teachers of his master. Ba Kathir's erstwhile mentor in Lamu, Sayyid Mansab b. Abd al-Rahman (1829-1922), spent two periods in Mecca, both times studying with Dahlan, Babsayl and Shatta. In the early $20^{\text {th }}$ century, Ahmad b. Sumayt's son Umar

\footnotetext{
${ }^{14}$ BabSayl, Muhammad Said (1309/1891-92) Al-Qawl al-mujdi fi 'l-radd ala Abd Allah b. Abd al-Rahman alSind $l$, lithograph, Batavia (Jakarta).

${ }^{15}$ Snouck Hurgronje $2007: 184$.

${ }^{16}$ For a discussion of the intellectual formation of these generations of East African scholars generation, see A.S. Farsy (1989) Baadhi ya Wanavyoni wa Kishafi wa Mashariki ya Afrika/The Shafei Ulama of East Africa, ca. 1830-1970, (trans., ed. \& ann.) R.L. Pouwels, , African Primary Text Series, III, Madison: University of Wisconsin and. Bang (2003). See also, Abu Bakr al-Adani al-Mashhur (1412/1991-92) Lawami' al-nur. Nubdha min a'lam Hadramawt, 2 vols., Sanaa: Dar al-Muhajir and Abd al-Rahman b. Muhammad b. Husayn al-Mashhur (1984) Shams al-zahira al-dahiyya al-munira fi nasab wa-silsila ahl al-bayt al-nabawi, 2 vols., 2nd ed., edited by Muhammad Diya' Shihab, Jiddah: Alam al-Ma'rifa.
} 
followed suit, and spent a period in Mecca, amongst others with Dahlan's son. ${ }^{17}$ All these men came to be extremely influential in the East African scholarly community, and in their writings all of them make numerous references to Dahlan, Babsayl and Shatta.

However, the contact was not solely intellectual, but also practical. Turning to the actual waqf documents, it is clear that by the early $20^{\text {th }}$ century, there existed in Zanzibar several properties that had been made waqf (Islamic religious endowments) in the $19^{\text {th }}$ century for "the benefit of the poor of Mecca and Medina". Before the British proclamation of the Zanzibar Protectorate in 1890 and the subsequent establishment of the colonial Wakf Commission in 1905, the transfer of funds was a process undertaken by qadis (Islamic jurists) in Zanzibar with receipts duly produced from the qadis on the receiving and distributing end in Mecca and Medina. The tremendous growth of Zanzibar in the $19^{\text {th }}$ century, had made many rich enough to donate at least some of their property as waqf. ${ }^{18}$ In Zanzibar, the existence of the waqf properties themselves changed the face of the real estate market, much to the distress of the British who referred to waqf properties as a mortmain (dead hand), i.e. real estate removed from the market and thus also from taxation. Thus, the endowments themselves illuminate the history of Zanzibar as a $19^{\text {th }}$ century "boomtown".

However, the endowments and their handling also clearly has transoceanic aspects. The way these funds were transferred and distributed, the identities of the recipients, and how the entire enterprise was administered; all relied on long- standing cultural and personal contact. A survey of the waqf files ${ }^{19}$ in Zanzibar shows that the money was transferred through a close network of Islamic scholars which by-passed British control in favour of a network of men who knew each other personally through student/master relationships or through direct family connections. Interestingly, the distribution also favoured families who

\footnotetext{
${ }^{17}$ Umar b. Ahmad Sumayt (1955) Al-Nafhat al-Shadhdhiyya min al-Diyar al-Hadramiyya wa-talbiyyat alsawt min al-Hijaz wa-Hadramawt, privately printed: Tarim/Aden.

${ }^{18}$ As the registration of waqf endowments only became systematized after the establishment of the Wakf Commission in 1905, the actual number of waqfs endowed in Zanzibar Town in the $19^{\text {th }}$ century remain guesswork. However, as Abdul Sheriff has pointed out, around fifty mosques were built in the city during the $19^{\text {th }}$ century. The upkeep and personel for these mosques were paid for by revenues from waqf properties. This indicates that the percentage of real estate held as waqf must have been high, both in the city and the surrounding area. A. Sheriff (1992) "Mosques, Merchants and Landowners in Zanzibar Stone Town", Azania $271-19$.

${ }^{19}$ The so-called "Meccan waqfs" are in the Zanzibar National Archives, ZA-HD/10-5.
} 
were extremely influential in the period when these waqfs were established (late 19th century). Dahlan and Babsayl have already been mentioned as central teachers to a generation of East African ulama. For the Alawi segment, equally important were the teachers of the al-Hibshi family, whether located in Hadramawt or in Mecca. ${ }^{20}$ The individuals in this network were tied together by strong bonds, both in terms of family (being of common Sharifian ancestry), and in shaykh-disciple relationships which were considered binding both in this world and in the more metaphysical sense.

The distribution pattern also shows an awareness of how political ruptures affected individuals in other places. Consider, for example, the Zanzibari waqf revenues distributed to the Shatta family, i.e. the sons and relatives of the $19^{\text {th }}$ century teacher Abu Bakr Shatta. Originally, only small amounts were granted to the Shatta family which was considered less important than that of Dahlan, Babsayl and Hibshi. However, by 1929 - notably four years after the Saudi-Wahhabi takeover of Hijaz - the Shatta family are on the list as recipients of 25 Rupees. In 1930 they received a similar amount as their companions of the Dahlan, Hibshi and Babsayl families. By 1933, the qadis in Zanzibar had decided that no less than $1 / 4$ of the remitted amount was to be earmarked for the head of the Shatta family, Salih b. Abi Bakr Shatta ("for they are numerous and their students cannot be under one hundred according to what we have heard from persons who come from that place"). ${ }^{21}$ The Zanzibar qadi Shaykh Tahir al-Amawi could thus write privately to Salih b. Abi Bakr Shatta in Mecca, reminding him of the long history of this transfer system and assuring him that it would continue:

This surplus has been maintained since days long gone, but these days the revenue has been disrupted, and tears of sorrow flooded because of its ceasing, since the waqf was meant to be continued for years to come. I should inform you that the instructions/legal warrants (amr) originally passed by the hands of the late Sayyid Ahmad b. Sumayt and Shaykh Abd Allah Ba Kathir, then it was conducted by [the latter's son] Shaykh Abu Bakr b. Abd Allah Ba Kathir, and it was always sent to

\footnotetext{
${ }^{20}$ The influence of the al-Hibshis derive mainly from Ali b. Muhammad al-Hibshi (d. 1915 in Sayun, Hadramawt), author of the Mawlid al-Hibshi which came to be widely recited on the East African coast. For a more in-depth discussion on individuals such as Ali b. Muhammad al-Hibshi and their roles as teachers and holy men, see Bang (2003).

${ }^{21}$ Minutes of Meeting of the Wakf Commission, 25 May 1933. ZA-HD/10-5.
} 
Shaykh Umar Ba Junayd, [...] However, now it will resume every year as before or even with an increase - God willing. ${ }^{22}$

This long and convoluted history of money distribution, stretching over a century, demonstrates precisely what is very evident in the Indian Ocean port cities: "the awareness of elsewhere", the clear knowledge of another place (namely Mecca) - its people, its typical goods, foods and habits. In this case, the knowledge was utilized to ensure safe money distribution among "ones own", in the face of expanding Wahhabism in Arabia and British colonial interference in Zanzibar.

\section{Source 3: The Mosque of Habib Umar b. Sumayt (Shadhili mosque) at Diego Suarez (Antsiranana), Madagascar. Negotiated Identities}

The life of the Hadrami-Comorian-Zanzibari scholar and qadi Umar b. Ahmad b. Sumayt has been related elsewhere and will not be described in detail here. ${ }^{23}$ What will be discussed here is only the part of Umar b. Sumayt's career that was spent in Madagascar. The traces of his life there raises questions of identity, both in the local and translocal context.

Umar b. Sumayt arrived in the port city Diego Suarez in northern Madagascar most likely in 1926, having earlier returned from Zanzibar to Grand Comore to find his business there in a very bad state. He decided to try new trading grounds in Diego Suarez, where there were already several of his fellow Comorians and also fellow Hadrami-Alawi - among them Abd al-Rahman al-Saqqaf, by then the khalifa of the Shadhiliyya order in Northern Madagascar. $^{24}$

\footnotetext{
${ }^{22}$ Letter from Shaykh Tahir al-Amawi to Sali، b. Abu Bakr Shatta, 21 Shawwal 1348/22 April 1930. Amawi File I, Doc. No. 34, Maktaba Ahmad Al Bu Saidi, Muscat, Oman.

${ }^{23}$ A.K. Bang (2006) "My generation. Umar b. Ahmad b. Sumayt (1886-1973): Inter-generational network transmission in a trans-oceanic Hadrami Alawi family, ca. 1925-1973”, in L. Manger \& M. Assal (eds.) Diasporas within and without Africa - Dynamism, hetereogeneity, variation, Uppsala: Nordic Africa Institute.

${ }^{24}$ On the life of Abd al-Rahman al-Saqqaf, see I. Said, M. A. Chamanga \& N. J. Gueunier (1982) "Un Qasida Arabe en l'honneur de Sayyid Ahmad al-Kabir, missionaire de l'Islam à Madagascar de 1896 à 1919", Etudes Océan Indien 1: 137-48. See also A.K. Bang, forthcoming, on the tariqa Shadhiliyya of northern Madagascar.
} 
In Diego Suarez, Umar built a mosque just above the present-day harbour, on the site where the Mosqué Jacob stands today. According to informants in Diego Suarez, the mosque was built of wood and corrugated iron, and it had living quarters attached to it where Umar b. Sumayt lived and from where he conducted trade. ${ }^{25}$ He is said to have stayed there together with two fellow Comorians, Muhammad al-Aris and Ahmad al-Tabib. However, it was emphasized that despite his close connections with the Shadhiliyya on the Comoros and his family connections with several of its leaders in Madagascar, the mosque of Habib Umar was not the centre for the Shadhiliyya order in Diego Suarez. Rather, the Shadhiliyya of the region was then centered on Abd al-Rahman al-Saqqaf in Ambilobe, a city south of Diego Suarez . The present Shadhili mosque in Diego Suarez was constructed later, on a piece of land which was originally owned by one "Ashraf" (said to have been the name of a man from Grande Comore) near to the French cemetery. This Ashraf then gave the land to the Comorian community for the construction of a Shadhili mosque. ${ }^{26}$

What all agree, though, is that the Shadhili mosque was constructed after Umar had built his own mosque in Diego Suarez - probably some time in the late 1920s or early 1930s. Emphasizing the importance of Comorian teachers in the spread of the Shadhiliya in Madagascar, the present day narrative states that the Shadhili mosque was built by all the Comorian community of Diego, including Umar b. Sumayt who also was known to teach in the mosque. However, Umar b. Sumayt is explicitly not included in the silsila (the spiritual chain) of the Shadhiliyya of Diego Suarez. Also, he did not stay very long in Madagascar. By 1936, he had left to take up a qadiship in Zanzibar.

Umar b. Sumayt returned to Madagascar one last time, shortly before his death in 1973. Informants disagree as to when this took place, but most likely it was in 1972, after Umar had settled in Itsandra in Grand Comore following his departure from Zanzibar in the wake

\footnotetext{
${ }^{25}$ This account of Umar b. Sumayt's activities in Madagascar is pieced together through several interviews: interview and conversations with members of the Ismail family, present day proprietors of the Jacob mosque, July 2008; interviews with Sh Bakar Momad and Sh Abdul Rasul, members of the tariqa Shadhiliyya in Diego Suarez, July 2008; interview with Sh. Abduh Samad, head of the present-day tariqa Shadhiliyya in Northern Madagascar, Ambilobe, July 2008; interview with Sh Yusuf and Sh Abduh Samash, present-day leaders of the tariqa Shadhiliyya in Diego Suares, July 2008; interview with Sh Abduh Samash, January 2007.

${ }^{26}$ According to some informants, it was Umar himself who owned this land, and who gave it to the Comorian community, but at present this cannot be verified from any written sources.
} 
of the 1964 revolution and his subsequent departure from Yemen in 1967. According to one informant of the Ismail family, he was already ill at this point and died shortly after his return. Upon this last visit, he spent much time in the Shadhili mosque and, according to all informants, "all of Diego" turned out to greet him, visit and talk to him. However, he also returned to, and stayed at, the site where his own mosque had once stood, but which by that time had become the Jacob mosque. It was, by all accounts, a last return, a last meeting with his friends and companions in Madagascar.

Upon my initial visit to the Shadhili mosque in Diego Suarez, the recently appointed imam emphasized very strongly the close ties between the mosque and the great Comorian shaykh, Habib Umar b. Sumayt. ${ }^{27}$ His choice of identity for the shaykh struck me as interesting. In Zanzibar, both Umar b. Sumayt and his father Ahmad are perceived as great Zanzibari scholars of the past and included in every presentation of Zanzibari Islamic history. Similarly, in Hadramawt, the father and son Sumayt, who lived and worked in East Africa, were portrayed as Hadrami Alawis - their books being piously stored in manuscript and printed form in the libraries of Tarim.

So, why would the staff of the mosque in Diego Suarez choose to emphasize Umar b. Sumayt as a Comorian? Why not take the step further, and call him Malagasy? Notwithstanding the fact that Malagasy identity is closely tied to language and culture, Umar had French citizenship towards the end of his life, and in that context he could conceivably be referred to Malagasy if there was any reason for it. The answer could be that the imam perceived himself as a Comorian, being one generation away from Grande Comore. The mosque itself is one of several focal points for the large Comorian community in Diego Suarez, a community that at times has felt alienated from the Malagasy mainstream, while at times being the local engine of commerce in the northern region of Madagascar. Thus, the need to emphasize a particular identity for a long-dead shaykh was both personal, political, and religious.

\footnotetext{
${ }^{27}$ Interview with Sh Abduh Samash, January 2007.
} 


\section{Local Histories - Global Interpretations?}

The three cases presented above all originate from an ongoing research project tracing the expansion of Islam and Islamic ritual practice in the southwestern Indian Ocean. The sources (written and oral) testify to different types of connectivity, and in different ways they also testify to the impact of Islam on bounded local communities.

The first question which then needs to be addressed with relation to these type of sources is: When the global impacts on the local, which one is actually our field of study? Is it the global phenomenon and how it moves, spreads and changes -for example, Islam? In this view, Islam is the wind that crosses the sea, whereas the cities and nations are reefs and islands which it washes over on its way. Or is it the local - for example, the Muslim community in Cape Town or in Diego Suarez? Or is it neither - in the sense that, for example, change itself is our actual object of study? Or finally, could we say that the Indian Ocean as a cultural area is our object of study? If so, how do we best conceptualize the ocean? Many have tried to make this definition, a few may be quoted here: "A facilitator for cultural exchange, but also as a contested space"? ${ }^{28}$ "A relational configuration of permanently moving objects"? ${ }^{29}$ A "seascape"?

These are questions of perspective, a search for starting points. However, these are also questions that relate directly to the narration - or rather, the creation - of history, understood as the creation of what Kai Kresse and Edward Simpson have called a "people's sense of the past". 31 This sense, as Kresse and Simpson have pointed out, is created in localities and is inextricably linked to a sense of place, whether the "home" or the "away" locations with different connotations. Even for the most migrant of peoples, it is indeed difficult to imagine a past completely unrelated to place. It matters where you live and, as Engseng Ho has pointed out, in a society of migrants, what matters most is where you die -

\footnotetext{
${ }^{28}$ David Parkin, in a discussion during the workshop "Shifting the meaning: Connectivity and its challenges in the Western Indian Ocean", Berlin, May 2007.

${ }^{29}$ K. Bromber (2007) Indian Ocean without limits? The transformation of a seascape during World War II, unpublished paper.

${ }^{30}$ Project at the Zentrum Moderner Orient, Berlin, 2002.

31 Kresse \& Simpson (2007: 3).
} 
where your grave will be. ${ }^{32}$ Genealogies list where a person was born and where he died, and in the Indian Ocean, these may often be far apart, thus we have a record of movement. But we also have a record of place, of locations.

A second question thus arises: What precisely are our locations when we study Indian Ocean connectivity? One suggestion may be that the primary localities are the port cities and villages on the Indian Ocean coast that, by their infrastructure and their population, facilitate interaction with corresponding localities at another point on the same sea. In these localities, perceptions of the present world, and the past world, are created and re-created. In these localities are also produced what historians use as "sources"; be they written, material or transmitted in the form of narratives. The relationship between the source, its locality and the other locations it directly or indirectly refers to, is one that the historian of the Indian Ocean (or of the localities of the Indian Ocean) will need to ponder. Clarification of this relationship becomes more acute the more likely our sources are to address and have implications not only for the actual locale that produced it, but also for other, corresponding locales elsewhere on the shore. This translocal nature of the source influences not only the historian's interpretation, but also the interpretation (or "sense") of the past which takes place in that locale.

The sources discussed above are testimony to previously existing links and interrelationships, as well as of immigration, emerging cities and evolving ethnicities. Local, or at least regionally specific, interpretations of the sources shape relevant narratives, in a process which incorporates both social actors and observers. In the introduction to his much-cited work Genealogies of Religion, Talal Asad raises the question as to when and how history is being made - or more specifically; whose history is being made, for example in the process known as "modernization". ${ }^{33}$ Asad addresses what he sees as a Western cultural hegemony and how this guides our view of history, when and how it is produced, by whom and for whom. This paper follows Asad in his emphasis on history

\footnotetext{
${ }^{32}$ Ho (2006).

${ }^{33}$ T. Asad (1993) Genealogies of Religion. Discipline and Reasons of Power in Christianity and Islam, Baltimore: Johns Hopkins University Press.
} 
as being created by multiple narratives bounded by their own, distinct mode of interpretation, at times obscured by the Western mode of interpretation.

However, sources such as the ones presented above also call for special observation on how these multiple narratives/sources interact to construct translocal narratives. From them, we can construct a series of historical narratives that to a larger degree take into account the elsewheres which they implicitly refer to. In the first example, the Sayyid who disembarked in Cape Town is best read as an agent of the globalization of Islam, with a specific place in a specific network of like-minded scholars. When money was being transferred and receipts brought back between Mecca and Zanzibar, another corner of this same network was cemented with an added layer over that of Sufi brotherhood - money. Finally, when the imam of Diego Suarez promotes "Comorianess" over a whole range of other possible identities, he presents a narrative of both the past and the present which essentially links this network together, while at the same time stressing its local anchorpoints and its various local aspirations.

These sources could obviously have been read quite differently, in another relationship to its location - on immigration to South Africa, on Zanzibari real estate or on, say, the ethnic history of a Shadhili mosque in Diego Suarez. However, these sources tell us a history of links and interrelationships, as well as of immigration, emerging cities and evolving ethnicities.

Admittedly on thin evidence, it is tempting to try to read all three sources in a way that creates one, interrelated narrative on the patterns by which Islam (and particularly Sufioriented, tariqa-based Islam) spread through organized networks in the south-western Indian Ocean in the late $19^{\text {th }}$ and early $20^{\text {th }}$ century. However, for this narrative (or this creation of history) to stand, more substantial - and more substantially translocal - sources are needed. 


\section{Bibliography}

al-Mashhur, Abd al-Rahman b. Muhammad b. Husayn (1984) Shams al-zahira al-dahiyya al-munira fi nasab wa-silsila ahl al-bayt al-nabawi, 2 vols., 2nd ed., (ed.) Muhammad Diya' Shihab, Jiddah: Alam al-Ma'rifa.

al-Mashhur, Abu Bakr al-Adani, 1412/1991-92 Lawami' al-nur. Nubdha min a'lam Hadramawt, 2 vols., Sanaa: Dar al-Muhajir.

Arai, K. (2004) Arabs who traversed the Indian Ocean: The history of the al-Attas family in Hadramawt and Southeast Asia c. 1600-1960, PhD Thesis, University of Michigan.

Asad, T. (1993) Genealogies of Religion. Discipline and Reasons of Power in Christianity and Islam, Baltimore: Johns Hopkins University Press.

BabSayl, Muhammad Said (1309/1891-92) Al-Qawl al-mujdi fi 'l-radd ala Abd Allah b. Abd al-Rahman al-Sindl, lithograph, Batavia (Jakarta).

Bang, Anne K. (2003) Sufis and Scholars of the Sea. Family networks in East Africa, c. 1860-1925, London: Routledge-Curzon.

(2006) "My generation. Umar b. Ahmad b. Sumayt (1886-1973): Inter-generational network transmission in a trans-oceanic Hadrami Alawi family, ca. 1925-1973", in L. Manger \& M. Assal (eds.) Diasporas within and without Africa-Dynamism, hetereogeneity, variation, Uppsala: Nordic Africa Institute.

Becker, F. (2008) Becoming Muslim in Mainland Tanzania, 1890-2000, Oxford: Oxford University Press.

Bromber, K. (2007) Indian Ocean without limits? The transformation of a seascape during World War II, unpublished paper.

Chaudhuri, K.N. (1985) Trade and Civilization in the Indian Ocean: An economic history from the rise of Islam to 1750, New York: Cambridge University Press.

Dahlan, Ahmad Zayni (1980) Al-Durrar al-Saniyya fi 'l-radd al-Wahhabiyya, 4th ed., Cairo ND.

Farsy, A.S. (1989) Baadhi ya Wanavyoni wa Kishafi wa Mashariki ya Afrika/The Shafei Ulama of East Africa, ca. 1830-1970, (trans., ed. \& ann.) R.L. Pouwels, African Primary Text Series, III, Madison: University of Wisconsin.

Freitag, Ulrike (1999) "Hadramaut: A religious Centre for the Indian Ocean in the late $19^{\text {th }}$ and Early $20^{\text {th }}$ centuries?" Studia Islamica $89: 165-83$.

- (2003) "Der Orientalist und der Mufti: Kulturkontakt im Mekka des 19. Jahrhunderts", Die Welt des Islams, 43 (1): 37-60.

_ (2003) Indian Ocean Migrants and State Formation in Hadhramaut. Reforming the homeland, Leiden: Brill.

Ho, Enseng (2006) The Graves of Tarim. Genealogy and Mobility across the Indian Ocean, Berkeley: University of California Press.

Kresse, K. \& Simpson, E. (eds.) (2007) Struggling with History. Islam and Cosmopolitanism in the Western Indian Ocean, London: Hurst. 
Loimeier, R. (2006) “Zum sozialen Kontext eines religiösen Rituals”, Der Islam 83: 170186.

_ (2009) Between Social Skills and Marketable Skills. The politics of Islamic education in $20^{\text {th }}$ century Zanzibar, Leiden: Brill.

— \& Seesemann, R. (eds.) (2006) The Global Worlds of the Swahili. Interfaces of Islam, Identity and Space in $19^{\text {th }}$ and $20^{\text {th }}$ century East Africa, Munster: LIT Verlag.

Mobini-Kesheh, Natalie (1999) The Hadrami Awakening. Community and Identity in the Netherlands East Indies, 1900-1942, Ithaca: Cornell University (SEAP).

Pearson, M.N. (2003) The Indian Ocean, London: Routledge.

Prestholdt, J. (2008) Domesticating the World. African Consumerism and the Genealogies of Globalization, Berkeley: University of California Press.

Said, I., Chamanga, M.A. \& Gueunier, N.J., (1982) "Un Qasida Arabe en l'honneur de Sayyid Ahmad al-Kabir, missionaire de l'Islam à Madagascar de 1896 à 1919”, Etudes Océan Indien 1: 137-48.

Sheriff, A. (1992) "Mosques, Merchants and Landowners in Zanzibar Stone Town”, Azania 27: 1-19.

- (2009) Dhow Culture, London: Hurst.

Snouck Hurgronje, C. (2007) Mecca in the latter half of the $19^{\text {th }}$ century, Leiden: Brill, 205206.

Sumayt, Umar b. Ahmad (1955) Al-Nafhat al-Shadhdhiyya min al-Diyar al-Hadramiyya wa-talbiyyat al-sawt min al-Hijaz wa-Hadramawt, privately printed: Tarim/Aden. 